\title{
Retracing the Kurdish and the Armenian Issues in the Journal of Albayrak in Period of National Struggle in Turkey (1919-1922)
}

\author{
Cemile Burcu Kartal, Ezgi Ören \\ Ataturk University, Erzurum, Turkey
}

\begin{abstract}
World War I became a milestone in the decay of empires and in the transition to the form of nation-state all over the world. Also, the national identities had been emerged and shaped in this period, before and after of the war. Contemporaneously, the years between 1912 and 1922, constructing Turkish identitiy and nationalim provided the important components to the founding of the Republic in Turkey. Especially, 1919-1922 period was important in terms of this arising national movement, because of the era which was beginnig the transition from the empire to the nation-state with the accession of the whole society in a national struggle. Therewith, Treaty of Sevres and Mondros Armistice Agreement were considerable factors in acceleration of the struggle in Anatolia. Besides, local press had a curicial role in the occupied territories throughout the stage. And the Journal of Albayrak which came out in Erzurum was one of the foremost media vehicles in the period of national struggle in the east of country. Herewith, Albayrak stated that it would make contribution to the point of informing the community and raising consciousness about the reasons of Armenian problem and its forthcoming dangers. This journal, also, gave information and news concerning Kurdish issue that arised in this period. In this respect, the purpose of this paper is to examine the place or role of a journal as a propaganda material within a struggle of independence and constructing a nation state period of an occupied country by analysing its news. It is important to study Albayrak because it had important impact on area of the local press in the region which made news about Armenians and Kurds. Herewith, the study also intends to handle the approach of this media source to Kurdish and Armenian issues in the era and by this way tries to make any contribution to the related discussion.
\end{abstract}

Keywords: media, Journal of Albayrak, national identity, war, propaganda

\section{Introduction}

As it is known World War I became a milestone in the decay of empires and in the transition to the form of nation-state all over the world. Also, the national identities had been emerged and shaped in this period, before and after of the War. Construction of a nation firstly requires producing a national conciouness and identification. In this process, some basic items are used to describe the nation such as territory, language, religion, common history, culture etc. Besides, mass media has also an important role in reinforcing this identificaton as a propaganda instrument, especially in the wartimes.

Cemile Burcu Kartal, Ph.D., Ataturk University, Erzurum, Turkey.

Ezgi Ören, Ress. Asst., Ataturk University, Erzurum, Turkey.

Correspondence concerning this article should be addressed to Cemile Burcu Kartal, Ataturk University, Economics and Administrative Science Faculty, Dept. of Public Administration, no. 210, zip: 25030, Yakutiye-/Erzurum, Turkey. 
So, we purpose to examine a journal as an important propaganda material in a war time, in a certain place. This is the Turkish War of Independence (1919-1923) and the journal which is mentioned above is "Albayrak" (1919-1921) that issued in Erzurum, East Anatolia in these years.

This paper analyses that how a journal which was one of the most important examples of the local press in the region was utilized as an important propaganda material and what kind of rethoric it generated about both Kurdish and Armenian issues. And also the study proposes to find out the approach to these issues in foundation phase of republic in Turkey by the way of retracing a journal, Albayrak. Herewith, an additional purpose is to examine a media source which is not handled before by the means of Kurdish and Armenian questions and in this way to try to make any contribution to the related discussion.

Within the creation process of nation-state, basic point is the definition of the nation which will be constituted. Beside such notions for this description, territory, language, religion, lineage, etc., it could be said that mass media is an significant device in the construction of a nation.

One of the media sources which has a power to affect the formations or chances in societies is press and so journals. As history shows, journals had contributed to appearing a common sense among the members of the community. Particularly, in the time of wars and emergency, they had an important role in creation of social solidarity and cohesion by the way of representing the symbols against the common enemy (Ayhan, 2008).

So, we think of Albayrak as a local press; issued in the years of Turkish War of Independence (1919-1923) is one of the good examples for demonstration of mentioned importance and effect on the society becoming propaganda instrument with its news about Armenian and Kurdish affair in the era.

Before the entity of nation-states or in the case of a country that was sovereigned by the other forces, creation and development of national conciousness were required to gain national independence (Karakaş, 2000).

Through the creation process, it is important to define what and whom the nation is. While the definition specifies the contents, extents, and borders of "we" and "other", on the other hand it indicates the goal which is desired to reach at the end of the natonalization period. And this definition is generally composed by the terms of language, territory, lineage, religion, common history-culture notions, and common enemy, the image of the "other" (Erözden, 1997).

Improvement of culturel, intellectual, and social environment is necessary for imagining the nation as a whole according to Anderson. So this could be actualized by the help of some vehicles and one of them is mass media.

\section{Relation of Media and National Identification}

It is obvious that media has a relation with concepts of modernization and nation-state. It is content with important functions in chances and transformations of societies. It is also an instrument which entails solidarity and coalescence of society in extraordinary situations (Ayhan, 2008).

National identification in this era acquired new means of expressing itself in modern, urbanized, high-technology societies. Two crucial ones must be mentioned. The first, which requires little comment, was the rise of the modern mass media: press, cinema, and radio. By these means popular ideologies could be both standardized, homogenized, and transformed, as well as, obviously, exploited for the purposes of delibrate propaganda by private interests and states (Hobsbawm, 2000).

It should be said that the notable role of the media is to inform the people to obtain social integration within the transition period of empires to the nation-states. 
Imagining, forming, adaptation, and transformation of nations render extraordinarily the great wars of the 20th century.

We take it for granted that modern warfare involves all citizens and mobilizes most of them; that it produces untold destruction and utterly dominates and transforms the life of the countries involved in it (Hobsbawm, 1995).

Communication systems aimed to affect public opinion as regards national interests by the way of propaganda in the war times.

Propaganda had been used in World War I for the first time as a war vehicle. Announcements and declarations which were thrown from the planes had been effective both on the soldiers and people psychologically. Also, people could get information about the circumstances of the fronts from press. Propaganda had purpose to bring people together as well. According to Welch, for instance, propaganda is "the deliberate attempt to influence the opinions of an audience through the transmission of ideas and values for the spesific purpose, consciously designed to serve the interest of the propagandists and their political masters, either directly or indirectly" (Welch, 1999, as cited in Melissen 2005). If propaganda is to be a useful concept, as Nick Cull argues, "it first has to be divested of its pejorative connorarions". In this view, propaganda should be seen as a wide-ranging and ethically neutral political activity that is to be distinguished from categories such as information and education. What seperates propaganda from education or information (assuming that these two are uncontroversial and straightforward) is that it "tries to tell people what to think" (Cull, Culbert, \& Welch, 2003). Also, Barker writes that: the conscious intent of ruling elites to manufacture public consent, while not monolithic in its effectiveness - for the most part because of vigorous grassroots activism-still exerts a massive influence on the way people think about domestic matters and especially foreign affairs. (Barker, 2009, as cited in Klaehn \& Mullen, 2010).

Besides in another example as Kologlu said: a journal has a different function from the other sources of information that is reaching to many people at different levels of society simultaneously. Hence, the language of the journal is far from the scientificity by the reason of simplification, summation, and clarity in its narrative style. So, jounals do not produce science and idea, they just mold public opinion and mindset. Here this is the culture of journal or journalism (Kologlu, 2006).

Briefly, the same propaganda effect of the press which is mentioned above was seen in the Turkish Independece War period in Turkey. And the Journal of Albayrak could be shown as a good example in that means.

\section{The Journal of Albayrak Case}

In the age of emergence of nation-states and national identities, contemporaneously, the years between 1912 and 1922, constructing Turkish identitiy and nationalim provided the important components to the founding of the Republic in Turkey.

Especially, 1919-1922 period was important in terms of this arising national movement, because of the era which was beginnig from the transition from the empire to the nation-state.

Therewith, Treaty of Sevres and Mondros Armistice Agreement were considerable factors in acceleration of the struggle in Anatolia.

Besides, local press had a curicial role in the occupied territories throughout the stage. And the Journal of Albayrak which came out in Erzurum was one of the foremost media vehicles in the period of national struggle in the east of country. 
Albayrak had been published during two terms: 1913-1915 and 1919-1921. Herewith, it stated that it would make contribution to the point of informing the community and raising consciousness about the reasons of Armenian problem and its forthcoming dangers. This journal, also, gave information and news concerning Kurdish issue that arised in this period.

Albayrak had been published with the opening of the Defence of National Rights of Eastern Provinces Committee branch. So in the region it had functioned as medium of the "Defence of Rights" movements (Akbulut, 2006; Albayrak, 2009).

Albayrak, first pressed on March 14, 1913, was managed from the National Library in Erzurum. The journal was issued once or two times in a week and it tightly bounded to Turkism especially with regard to its written laguage and spelling (Coşar, unknown).

The journal had 93 volumes in its first term in between 1913-1915. But only two of them have been remained (Akbulut, 2006; Albayrak, 2009).

Its second term that is the subject to this study had been published between 1919-1921. After getting rid of the occupation in Erzurum, reanimation studies for the journal had been started through Mr. Necati Güneri's efforts and they had been entered brodcasting again on April 12, 1919. In accordance with Mondros Armistice Agreement which was signed on Ekim 30, 1918, Ottoman army obliged to withdraw to its 1914 borders. Therewith some officers and commanders convened temporary Government of the National Council on November 3, 1918, in Kars. According to the decisions of the council, local organizations had to ensure defending borders and national unity. In pursuance of this decision, Albayrak was given important duties likewise. Thus the journal was abided by Turkism by broadcasting on providing national unity. It followed a certain counter-political line about giving East Anatolia to Armenians and from its 34th issue, put a motto like "East Provinces could never be Armenia" under the headline of the newspaper (Akbulut, 2006).

In the beginning it was issued two days and later on once in a week as 131 volumes totaly (Akbulut, 2006; Albayrak, 2009).

Süleyman Necati, Cevat Dursunoğlu, Mithat Turanlı, and Müştak Sitki were the writers of the journal; the owner and the editor in chef was Süleyman Necati. After Süleyman Necati was elected as a deputy, Mithat Turanli became editorial writer (Akbulut, 2006; Albayrak, 2009).

The reason for the journal resumed; firstly, allies' occupation began along the Anatolia territories after the signing of Mondros Armistice Agreement and there was a prevalent apprehension about giving up the east provinces to the Armenians. These fears derived from the 24th article of the Agreement which intitled occupation to allies anywhere of the six east provinces (Vilayet-i Sitte), and those were named as Erzurum, Bitlis, Van, Diyarbakir, Sivas, and Elaziğ (Ma'muretil'aziz) in any disordering situation.

Herewith, the journal made a slogan as headline that "Eastern Provinces could never be Armenia" unto volume 122. This catchword was replaced with "Eastern provinces is the homeland of Turks" after 122nd issue. Main reason for this alteration was the signing of Treaty of Alexandropol (Gümrü) and recognized East Borders of the Ottoman because of this agreement.

\section{Publishing Policy of the Journal in Its Second Term}

As a matter of fact, Albayrak put the Armenian issue core of its publishing policy by reissuing. From its first volume, it had made news about activities and atrocities of Armenian policy in East Anatolia and peripheral regions. Also it had published various articles arguing that the region was not likely to be an 
Armenian country for historical, religious, and cultural reasons.

Majority of news were about the Armenian violence besides all the other news about Armenians. The journal included a column which was named like "From the Armenian Atrocities".

The news placed which were pointed out the activities of other countries, especially Great Britain, in the region as well (issue 6, April 22, 1919).

Reports of Armenian violence that had happened in Erzurum and regions nearby, also took part alongside the ones arriving from Azerbaijani, Qarabag, and Nakhichevan (Albayrak, 1919).

News about Armenians especially with negative content had been quoted from national and international journals (Albayrak, 1919).

Kurds had been another topic that Albayrak newspaper had put emphasis on. It had been handled within the line of Armenian issue. The possibility of separation of Kurds from Turks by manipulation of Armenians had been drawn attention, and the journal had highlighted the threat of a possible Kurdish separationism. However, religious unity with Kurds had been frequently emphasized in related columns.

There are some examples for the contents of the related news from the journal below:

On its 34th issue, the journal published a letter called "the Application of Armenians to Kurds" and the response of Kurdish tribal chiefs was in return. However, it mentioned about the disloyalty of Armenians and their efforts to slaughter Islam and Muslims continuing nearly five years. So it stressed that depending on these reasons Kurds and Armenians could not gather (Albayrak, 1919).

Another example warning Kurds against Armenians is the editorial of 40th issue; arguing East Anatolian Turks and Kurds could not seperate from each other and citing about "Kurdistan" would pave the way for an Armenian invasion (Albayrak, 1919):

Today, continuity of domination of Islam in Eastern Anatolia depends on the unity of the Kurds and Turks. As we have expressed recurrently before, Kurds and Turks of Eastern Anatolia are mingled together. In this way, trying to segregate Kurds and Turks who are jointly members of a family means to attack sanctity. Thereby, dicussing on the construction of Kurdistan does not make another sense from feeding or encouraging Armenian incursion.

In another remarkable article, eastern region had been pointed out as Turkish native land and the history of initial arrival of Turkish tribes to Anatolia was reported. The writing continued as arguing that Turks had not met any Armenian existence there when they arrived in Anatolia for the first time and at the time Armenians had been broken off their national unity and declined. It had also asserted that historical facts had proved the thesis suggesting Eastern Anatolia was Turkish Land (Albayrak, 1919).

Kurdish uprisings within aforesaid period had been seen as Armenian intrigues and again and again it emphasized that Kurdish and Turkish nations were bounded by religion and brotherhood in the newspaper. Nevertheless, Kurds had been warned about the exposing the region with uprisings against Anatolia would render foreign states' invasion (Albayrak, 1919).

The expression "Religious brotherhood with Kurds" had been brought out by K15 commander Kazim. Karabekir is another outstanding point with the emphasis of thoses two nations which had rooted from same race (Albayrak, 1919):

Turks and Kurds had lived together and united under Islam flag for centuries. Hence, East Anatolia is the land of both, Kurds and Turks. Contrary approaches which try to prove that two are different will bring on destruction for both societies. The only obstacle to prevent Armenian activities is the unity of Turks and Kurds under Islam flag. (Albayrak, 1919) 
One another remarkable point in the journal is the emphasis on that eastern people have right to say in Kurdish question more than people living in Istanbul. Also, it was specified that Istanbul could not have right informations about the affairs in Anatolia. Besides, there were some articles in reply to the newspaper issued in Istanbul which made propaganda about the establishment of Kurdistan. This newspaper criticized the poverty of aggrieved Kurdish people in the region but these arguments were answered by the Albayrak and it stated that Kurdish and Turkish people were living in the same conditions.

"Therefore, the economical or political opponents of Kurds are also the opponents of Turks now and in the future. Because of much more reasons of the interests of Turks and Kurds will be common as before" (December 28, 1919, issue: 56).

Also in same article, it is suggested that Kurds and Armenians could not act and live together. Because of deep religious, cultural, and historical differences; idea of Armenian domination over Kurds would not be eventuated further than a dream. Accepting Armenian sovereignty means to ignore honor, sanctity, historical facts and become inhuman (Albayrak, 1919).

\section{Conclusion}

Albayrak was the foremost medium of press in the National Strugle period in Turkey. The journal had been effective both in the region and in whole land of Anatolia so that it was forbiden to distribute in Istanbul by the governance of Istanbul because of its contents and the close relationship with the Government of Ankara (Birinci, 1999).

By making a strong counter action against the propagandas of Armenians, The Albayrak took quite influential place in the defense of the East Provinces' Rights.

In consideration of the journal's glance at the Armenian and Kurdish case, it could be seen easily that there were similarities between the policies of Ankara Government and the journal's line in making news.

As narrating especially the problems with the Kurds, emphasis on the unity of religion in the writings of the journal could be counted the most important indicator to this parallelism with government policies. For the reason that Government of Ankara was used mostly the religious items in his discourses in the national struggle times (Yildiz, 2009).

For the term, the dominant institution was religion. Integrative role of the religious institutions had been used in National Struggle period for the unity of the society. And religious discourses took the place of nationalist highlights in the era between 1919-1923 (Yildiz, 2009).

The Journal of Albayrak was closed down in 1922. The story of closing could be subject of a different study. But as if the closure period proved the reality that the journal's writing policies had been determined and controlled by the central government. Being establihed by Committee of Union and Progress for the first time in 1912, publicated in the name of the "Defence of Rights" and even closing period had indicated its statist side (Yurdigül, 2000).

Albayrak was a journal which depended on the idea of Turkism and nationalism in its publications. Yet, by the end of the year 1919, it had lived some changes in its policies with shifting of editorial staff. In the era, developing close relationship with the Bolshevik Revolution between Ankara and SSCB caused to increase the number of left side writings in the journal. However, after a while, the content of the articles overcame the purpose ideologically and under these circumstances the relations with the Government of Ankara began to go 
wrong. Lastly, after arresting of the editor in chef in 1921, Albayrak was closed down (Albayrak, 2009; Yurdigül, 2000).

As a summery, at the end of the this study, it could be seen easily that the Journal of Albayrak had been one of the foremost propaganda vehicles and it made influencial news about Armenians and Kurds in the region until its end. With the second commencement of its publishing cycle, it had put Armenian issue to the center of its publishing policy. And it had effective role in defending the rights of Eastern provinces by building up a strong anti-propaganda activity against Armenian. Even if it is a kind of propaganda vehicle like its similars in whole world universally, Albayrak was established firstly to intend for informing society about the circumstances in the fronts and events in the region and also to raise awareness about future of their occupied country in nation-building process. As a result, it is obvious that the journal had influential place or role as a propaganda material within defence of a country which had wishes to provide its territorial integrity.

However, collapse of the Ottoman Empire created a general tragedy that influenced all the people of the Empire-Turks, Greeks, Armenians, Arabs, Jews, and others, all of whom have traumatic memories of the period. So, it is the interest of all concerned that all sources be examined without preconception or prejudice (Shaw, 2005). And the approach of the Albayrak should be also evaluated in its circumstances and conjuncture.

\section{References}

Akbulut, \& Dursun, A. (2006). Albayrak Olayı: Milli Mücadele Başlarında Halk Hükümeti Kurma Girişimi Erzurum 1920, 16-42. İstanbul: Temel Yayınları.

Anderson, \& Benedic. (2006). Imagined communities: Reflections on the origin and spread of nationalism, 144. London:Verso.

Albayrak. (2009). Yüce Yurt’tan Yükselen Ses: Albayrak 1919-1921, Tipkı Basım ve Yeni Türk Alfabesiyle. Y. Aslan (Ed.). Erzurum, 1-30. Atatürk Üniversitesi Yayinlari.

Ayhan, \& Bünyamin. (2008). Olağanüstü Durumlarda Toplumsal Dayanışma ve Bütünleşmeye Basının Katkısı: Milli Mücadele Dönemi Basını. Konya, Selçuk Üniversitesi Sosyal Bilimler Dergisi, 9, 1.

Birinci, \& Ali. (1999). Süleyman Necati Güneri Hatıra Defteri, p. 35. Erzurum: Erzurum Kitapliği.

Coşar, \& Ömer, S. (unknown). Milli Mücadele Basını, p. 199. İstanbul: Gazeteciler Cemiyeti.

Cull, Nicholas, J., Culbert, David, \& Welch. (2003). Propaganda and mass persuasion: Historical encyclopedia, 1500 to the present, 15-21. Oxford and Santa Barbara CA: ABC-Clio.

Erözden, \& Ozan. (1997). Ulus-Devlet, 63-68. Ankara: Dost Kitabevi Yayinlari.

Hobsbawm, \& Eric. (1995). The age of extremes: a history of the world, 1914-1991, p. 40. UK, Abacus.

Hobsbawm, \& Eric. (2000). Nations and nationalism since 1780: Programme, myth, reality UK, p. 141. Cambridge University Press.

Karakaş, \& Mehmet. (2000). Türk Ulusçuluğunun İņ̧ası, p. 74. Ankara, Vadi Yayınları.

Klaehn, \& Jeffry-Mullen, A. (2010). The propaganda model and sociology: Understanding the media and society, p. 11. Sociology Faculty Publications.

Koloğlu, \& Orhan. (2006). Osmanlı'dan 21. Yüzyıla Basın Tarihi, p. 19. İstanbul: Pozitif Yayınları.

Melissen, \& Jan. (2005). The new public diplomacy, clingendael, Netherlands Institute of International Relations. Clingendael Diplomacy Papers , 2, 20.

Shaw, J., \& Stanford. (2005). Ottoman empire and modern Turkey. Reform, revolution, and republic: The rise of Modern Turkey, 2(5),1808-1975. Cambridge University Press.

Yildiz, \& Ahmet. (2009). Kemalist Milliyetçilik. Modern Türkiye'de Siyasi Düşünce: Kemalizm, 2, 221-224. İstanbul: İletişim Yayınları.

Yurdigül, \& Yusuf. (2000). Milli Mücadele’nin Sesi Erzurum Albayrak (Yerel) Gazetesi ve Ulusal Düzeydeki Etkileri Üzerine Bir Yaklaşım Denemesi, 10, 213-216. İstanbul: İstanbul Üniversitesi İletişim Fakültesi Dergisi.

\section{Journal News}

Albayrak, 22 April 1919/issue: 6, p. 1

Albayrak, 18 September 1919/issue: 28, p. 1 
Albayrak, 18 August 1919/ issue: 20, p. 1

Albayrak, 30 October, 1919/issue: 40, p. 1 Albayrak, 9 November 1919/ issue 43, p. 1 Albayrak, 7 December 1919/Issue: 50, p. 1

Albayrak,14 December 1919/ issue: 52, p. 1

Albayrak, 28 December 1919/issue: 56, p. 1 